Volume 12, Nomor 2, November 2020, pp 313-326 Copyright (C) 2017

Jurnal Akuntansi, Program Studi Akuntansi, Fakultas Ekonomi, Universitas Kristen Maranatha. ISSN 2085-8698 | e-ISSN 2598-4977. http://journal.maranatha.edu

\title{
Pengaruh Insentif Keuangan dan Kompleksitas Tugas Terhadap Kinerja: Sebuah Studi Eksperimen
}

\author{
Clara Noviana Agustina Indriastuti \\ Jurusan Akuntansi, Fakultas Bisnis, Universitas Katolik Widya Mandala Surabaya \\ (J1. Dinoyo 42-44, Surabaya 60265) \\ novclara@gmail.com \\ Adriana Marini Purwanto \\ Jurusan Akuntansi, Fakultas Bisnis, Universitas Katolik Widya Mandala Surabaya \\ (J1. Dinoyo 42-44, Surabaya 60265) \\ marini@ukwms.ac.id \\ Theodorus Radja Ludji \\ Jurusan Akuntansi, Fakultas Bisnis, Universitas Katolik Widya Mandala Surabaya \\ (Jl. Dinoyo 42-44, Surabaya 60265) \\ theodorusradja@ukwms.ac.id
}

\begin{abstract}
This study used a $2 \times 2$ between-subject experiment to examine the relationship between monetary incentives, task complexity and performance. Monetary incentives in this study were applied in two types, piece-rate and fixed-rate, while task complexity was varied in two categories, low and high. Participants' performance was measured through the completion of tasks assigned. Results of this study indicates no effect of monetary incentive on performance, yet there is a significant effect of task complexity on performance where participants provided with tasks with low complexity showed a significantly higher performance than participants provided with tasks with high complexity. Furthermore, this study finds no interaction between monetary incentives and task complexity on performance. It is implied from this study that monetary incentives were not the main factors that contribute towards employees' performance in the companies. Besides, task complexity is an important factor to be considered by firms, as it can influence their employees' performance.
\end{abstract}

Keywords: Monetary Incentives, Task Complexity, Performance 


\begin{abstract}
Abstrak
Penelitian ini menggunakan metode eksperimen $2 \times 2$ between-subject, untuk melihat hubungan antara insentif keuangan, kompleksitas tugas dan kinerja. Insentif keuangan dalam penelitian ini diaplikasikan dalam dua jenis, yaitu piece-rate dan fixed-rate, sedangkan kompleksitas tugas dibedakan dalam dua kategori, yaitu rendah dan tinggi. Adapun kinerja partisipan diukur lewat penyelesaian tugas yang diberikan. Hasil penelitian ini menunjukkan bahwa insentif keuangan tidak berpengaruh terhadap kinerja, namun terdapat pengaruh yang signifikan dari tingkat kompleksitas tugas terhadap kinerja, dimana partisipan yang diberikan tugas dengan tingkat kompleksitas rendah menghasilkan kinerja yang secara signifikan lebih tinggi dibanding partisipan dengan tingkat kompleksitas tugas tinggi. Lebih lanjut, penelitian ini tidak menemukan adanya pengaruh interaksi antara insentif keuangan dan kompleksitas tugas terhadap kinerja. Penelitian ini memberikan implikasi bahwa insentif keuangan bukan merupakan faktor utama yang mempengaruhi kinerja karyawan di dalam perusahaan. Selain itu faktor tingkat kompleksitas dari tugas yang diberikan oleh perusahaan kepada karyawannya adalah hal yang penting untuk diperhatikan, sebab kinerja karyawan dapat dipengaruhi oleh hal tersebut.
\end{abstract}

\title{
Kata Kunci: Insentif Keuangan, Kompleksitas Tugas, Kinerja
}

\section{Pendahuluan}

Di dalam aktivitas organisasi, salah satu fungsi dari akuntansi manajemen adalah sebagai penyedia informasi yang dapat digunakan oleh pengambil keputusan dalam organisasi untuk mengevaluasi dan memberi penghargaan kepada karyawan serta memainkan peran penting dalam memotivasi para personil di dalam organisasi untuk mencapai kinerja yang optimal (Hilton dan Platt, 2011). Selain itu, informasi akuntansi manajemen juga dapat digunakan oleh manajer untuk memilih dan menetapkan strategi perusahaan yang dirasa sesuai serta menjalankan sistem pengendalian manajemen (Hall, 2011). Dalam hal ini, sistem pengendalian manajemen berfungsi untuk membantu manajer untuk memutuskan strategi yang diharapkan mampu untuk mengarahkan perilaku karyawan secara strategis sehingga kinerja yang dihasilkan oleh mereka dapat sesuai dengan tujuan organisasi secara keseluruhan (Hall, 2011).

Kinerja adalah salah satu bagian penting dari apa yang ingin dicapai oleh karyawan maupun perusahaan. Gong dan Ferreira (2014) menyatakan bahwa kinerja organisasi secara keseluruhan dapat meningkat secara proporsional ketika kinerja individu yang ada didalamnya juga mengalami peningkatan. Oleh sebab itu, perusahaan akan berupaya untuk memperoleh cara yang dinilai efektif untuk meningkatkan kinerja karyawannya. Adapun kinerja sendiri juga merupakan cerminan dari kemampuan perusahaan dalam mengelola dan mengalokasikan sumber daya yang mereka miliki secara optimal, serta merupakan cerminan atas ketercapaian dari tujuan perusahaan yang telah ditetapkan (Chow, 1983).

Peningkatan kinerja karyawan dapat dilakukan dengan memberikan motivasi. Motivasi akan menggerakkan perilaku dan usaha karyawan untuk mencapai kinerja yang diharapkan oleh perusahaan. Salah satu bentuk motivasi yang dapat diberikan oleh organisasi adalah dengan pemberian insentif keuangan (Bonner, Hastie, Sprinkle dan Young, 2000; Bonner dan Sprinkle, 2002). Kompensasi atau insentif keuangan bagi perusahaan dapat dikatakan sebagai sebuah imbal balik atau penghargaan secara 
moneter yang diberikan pada karyawan yang telah memberikan upayanya untuk membantu perusahaan mencapai tujuannya (Bonner dan Sprinkle, 2002). Lebih lanjut, dikatakan pula bahwa insentif keuangan juga merupakan alat untuk membangun dan memelihara karyawan agar dapat bekerja dengan lebih produktif (Sudarma, 2012). Untuk menunjang peningkatan kinerja individu, pemberian skema insentif yang sesuai perlu dipertimbangkan oleh organisasi, sebab efektivitas kinerja dapat dipengaruhi oleh hal tersebut (Bonner dkk., 2000). Skema insentif yang sesuai dan disertai dengan komitmen untuk mencapai tujuan organisasi akan dapat mengarahkan karyawan pada peningkatan kinerja.

Sementara itu, Bonner dan Sprinkle (2002) juga menyatakan bahwa selain faktor insentif terdapat pula faktor lain yang dapat mempengaruhi kinerja karyawan, salah satunya adalah tingkat kompleksitas tugas. Kompleksitas tugas sendiri diartikan sebagai tingkat kerumitan dari elemen yang melekat didalam tugas yang dikerjakan oleh seseorang, dimana tugas yang tingkat kompleksitasnya tinggi akan membutuhkan usaha dan persistensi yang secara substansial juga lebih tinggi dibandingkan dengan tugas yang tingkat kompleksitasnya rendah (Liu dan $\mathrm{Li}, 2012$ ). Oleh karena itu, maka kompleksitas tugas dapat dijadikan sebagai salah satu faktor esensial yang perlu dipertimbangkan oleh organisasi untuk menentukan kinerja individu sehingga dapat mengarah pada efektivitas dan efisiensi yang umumnya diharapkan oleh organisasi (Bonner dan Sprinkle, 2002). Lebih lanjut, Liu dan Li (2012) serta Iskandar dan Sanusi (2011) berpendapat bahwa ketika karyawan memperoleh pekerjaan dengan tingkat kompleksitas tugas yang dirasa sesuai, maka pengerjaan tugas akan mampu berjalan dengan lebih efektif dan hal tersebut dapat memotivasi dirinya untuk menghasilkan kinerja yang optimal.

Berdasarkan berbagai penjelasan mengenai insentif keuangan, kompleksitas tugas dan kinerja, maka peneliti mencoba untuk mengkaji pengaruh pemberian insentif keuangan dan faktor kompleksitas tugas terhadap kinerja individu. Penelitian yang menggunakan metode eksperimen ini bertujuan untuk melihat hubungan secara empiris antara jenis insentif keuangan yang diaplikasikan oleh organisasi, tingkat kompleksitas dari tugas yang diberikan oleh organisasi untuk para karyawannya, serta kinerja yang dihasilkan.

Dengan meneliti hubungan antara faktor-faktor tersebut, diharapkan penelitian ini akan mampu memberikan kontribusi secara akademis terhadap kebaruan literatur penelitian di bidang akuntansi manajemen, akuntansi keperilakuan dan pengukuran kinerja, serta mampu memberikan kontribusi secara praktek dimana hasil dari penelitian ini diharapkan mampu digunakan oleh para pengambil keputusan dalam organisasi sebagai bahan pertimbangan dalam menyusun pemberian insentif dan menetapkan tingkat kompleksitas tugas yang sesuai bagi para karyawan, sehingga kinerja mereka akan dapat berada pada tingkat yang diharapkan oleh organisasi.

\section{Kerangka Teoritis dan Hipotesis}

\section{Insentif Keuangan}

Insentif keuangan merupakan pemberian kompensasi dalam bentuk nominal nilai uang dari satu pihak ke pihak lain atas dasar balas jasa terhadap kontribusi yang diberikan (Bonner dan Sprinkle, 2002). Insentif merupakan salah satu faktor yang dapat memotivasi karyawan untuk melakukan sesuatu bagi perusahaan. Skema insentif yang dirancang dan diterapkan dengan baik dapat menghasilkan pengaruh yang efektif terhadap produktivitas, efektifitas, efisiensi, maupun kualitas pekerjaan Bonner dkk. (2000). Dalam hal ini, beberapa contoh umum dari skema insentif keuangan menurut Bonner dan Sprinkle (2002), adalah skema insentif berbasis tarif tetap (flat-rate) dan tarif per unit (piece-rate). 
Sistem pemberian insentif dengan skema flat-rate memiliki nominal yang tetap. Dalam skema insentif ini, individu akan memperoleh kompensasi dengan nominal yang sama untuk suatu pekerjaan yang dikerjakannya, baik individu tersebut telah mengerjakan pekerjaan sesuai target, dibawah target maupun diatas target, individu tersebut akan tetap memperoleh nominal insentif yang sama (Bailey dan Fessler, 2011). Adapun salah satu contoh dari skema flat-rate adalah gaji tetap yang diterima oleh karyawan setiap bulannya dari perusahaan tempatnya bekerja. Di sisi lain, insentif dengan skema piece-rate merupakan suatu sistem pembayaran insentif yang diberikan secara variabel untuk setiap unit pekerjaan yang berhasil diselesaikan (Bailey dan Fessler, 2011). Dalam hal ini, Bonner dan Sprinkle (2002) juga menyatakan bahwa skema insentif piece-rate merupakan suatu skema yang memasangkan antara jumlah unit yang dihasilkan oleh setiap individu dalam suatu waktu dengan nominal insentif yang berlaku untuk setiap unit tersebut. Sehingga dalam skema piece-rate, semakin banyak unit produksi yang mampu dihasilkan, semakin banyak insentif yang diterima.

\section{Kompleksitas Tugas}

Kompleksitas tugas didasarkan atas persepsi dalam diri individu mengenai tingkat kesulitan dari tugas yang dikerjakannya berdasarkan pada karakteristik secara umum maupun spesifik dari tugas tersebut (Bonner dan Sprinkle, 2002). Lebih lanjut, Iskandar dan Sanusi (2011) menyatakan bahwa kompleksitas tugas memiliki tiga dimensi, yaitu komponen, koordinatif dan dinamis. Dimensi pertama adalah kompleksitas komponen, dimana hal ini muncul apabila terjadi peningkatan dalam hal tindakan dan informasi yang diperlukan untuk menyelesaikan tugas tertentu. Dimensi kedua yaitu kompleksitas koordinatif, dimana hal ini muncul jika terjadi peningkatan kebutuhan untuk mensinkronkan antara informasi, tindakan, dan produk atau output yang dihasilkan. Dimensi ketiga yakni kompleksitas dinamis, muncul apabila terjadi peningkatan terkait permintaan dalam hal penyesuaian perilaku serta pemrosesan informasi dari individu yang melakukan tugas tersebut. Oleh sebab itu dapat disimpulkan bahwa semakin kompleks sebuah tugas, semakin tinggi pula usaha, perhatian, konsistensi, serta waktu yang dibutuhkan oleh seseorang untuk menyelesaikan tugas tersebut (Iskandar dan Sanusi, 2011).

\section{Kinerja}

Sudarma (2012) menyatakan bahwa kinerja merupakan sebuah hasil yang dapat diperoleh dari suatu organisasi dimana organisasi tersebut dapat bersifat profit oriented atau non-profit oriented yang dihasilkan selama satu periode waktu. Sejalan dengan hal tersebut, Moeheriono (2012) menyatakan bahwa kinerja merupakan hasil kerja dimana individu telah mencapai pelaksanaan tugas dengan tanggung jawab baik secara kualitas ataupun kuantitas. Selain itu, Gong dan Ferreira (2014) menyatakan pula bahwa kinerja merupakan gambaran tingkat pencapaian individu atas pelaksanaan suatu kegiatan atau program untuk mewujudkan sasaran, tujuan, misi, dan visi organisasi. Sehingga dapat disimpulkan bahwa kinerja adalah hasil dari pekerjaan yang dicapai oleh individu dalam menyelesaikan tugas yang dikerjakan sebagai wujud pencapaian tujuan organisasi.

\section{Hubungan Antara Insentif Keuangan Dengan Kinerja}

Menurut Moeheriono (2012) kinerja merupakan gambaran tingkat pencapaian individu atas pelaksanaan suatu kegiatan atau pelaksanaan suatu program untuk mewujudkan tujuan yang ingin dicapai. Kinerja merupakan suatu bagian yang penting dalam sebuah perusahaan karena mencerminkan berhasil atau tidaknya perusahaan dalam mencapai tujuan yang 
telah ditentukan. Perusahaan perlu untuk memperhatikan pemberian skema insentif yang sesuai dengan usaha, keterampilan, dan kemampuan karyawannya. Ketika karyawan merasa insentif yang diberikan telah sesuai, karyawan dapat termotivasi untuk melakukan pekerjaannya. Motivasi yang berupa pemberian insentif yang sesuai akan menggerakkan perilaku karyawan untuk mencapai tujuan dari perusahaan (Oktavia, Rossieta dan Gani, 2014).

Insentif keuangan dengan skema piece-rate memungkinkan hasil kinerja yang lebih tinggi dibandingkan flat-rate karena individu akan diberi kompensasi pada setiap unit pekerjaan yang mereka kerjakan sehingga membuat individu tersebut lebih termotivasi, sebab besarkecilnya insentif yang akan diperoleh bergantung pada kinerja yang dihasilkan oleh individu tersebut (Bonner dkk., 2000). Hal ini sejalan dengan penelitian Oktavia dkk. (2014) yang menyatakan bahwa individu yang menerima insentif keuangan berskema piece-rate dapat memiliki kinerja yang lebih baik dibanding individu yang memperoleh insentif keuangan dengan skema flat-rate. Oleh karena hal itu, maka hipotesis yang dikembangkan adalah sebagai berikut:

$\mathbf{H}_{\mathbf{1}}$ : Individu yang diberi insentif keuangan dengan skema piece-rate akan memiliki kinerja yang lebih tinggi dibanding individu yang diberi insentif keuangan dengan skema flat-rate.

\section{Hubungan Antara Tingkat Kompleksitas Tugas Dengan Kinerja}

Dalam konteks pekerjaan, setiap orang akan termotivasi untuk melakukan tindakan tertentu yang mereka yakini akan mampu mengarah pada pencapaian tujuan yang diharapkan. Kompleksitas tugas merupakan salah satu komponen yang dapat dipertimbangkan oleh individu dalam melakukan tugasnya, dimana tingkat kompleksitas tugas yang dilakukan dapat berkaitan dengan ekspektasi dari individu tersebut terhadap kemungkinan penyelesaian tugasnya (Haerem, Pentland dan Miller, 2015). Selain itu, Liu dan Li (2012) juga mengemukakan bahwa tingkat kompleksitas tugas berhubungan dengan karakteristik yang melekat pada tugas yang diberikan, seperti ukuran, jumlah, variasi dan ambiguitas. Dalam hal ini, sebuah tugas yang kompleks akan memiliki ukuran, jumlah, variasi dan ambiguitas yang lebih tinggi dibanding tugas dengan kompleksitas yang rendah.

Bonner dan Sprinkle (2002) mengemukakan bahwa ketika tugas yang dilakukan oleh individu memiliki tingkat kompleksitas yang masih dapat dijangkau olehnya, maka kinerja dari individu tersebut akan dapat dihasilkan pada tingkat yang lebih tinggi dibanding dengan individu yang diberikan tugas yang lebih kompleks. Oleh sebab itu, dapat dikatakan bahwa individu yang diberi tugas yang sulit untuk dilakukan, lebih banyak atau tinggi dari segi ukuran maupun jumlah akan cenderung lebih sulit untuk dapat meningkatkan kinerjanya (Haerem dkk., 2015). Hal ini didukung pula oleh hasil penelitian Bailey dan Fessler (2011) yang menemukan bahwa kinerja individu akan cenderung lebih meningkat ketika mengerjakan tugas pada tingkat kompleksitas yang masih dapat dijangkau. Atas penjelasan tersebut, maka hipotesis yang dirumuskan adalah sebagai berikut:

$\mathbf{H}_{\mathbf{2}}$ : Individu yang diberi tugas dengan tingkat kompleksitas rendah akan menghasilkan kinerja yang lebih tinggi dibanding individu yang diberi tugas dengan tingkat kompleksitas tinggi.

\section{Hubungan Antara Insentif Keuangan,} Tingkat kompleksitas Tugas dan Kinerja Kinerja individu dapat dipengaruhi oleh beberapa faktor, diantaranya insentif keuangan dan tingkat kompleksitas tugas. Tugas yang kompleks dapat melibatkan lebih banyak hal yang perlu untuk dikerjakan secara lebih detail (Liu dan $\mathrm{Li}$, 2012). Selain itu tugas yang kompleks juga 
akan membutuhkan strategi khusus untuk dapat diselesaikan (Bonner dkk., 2000).

Berkaitan dengan hal tersebut, Bailey dan Fessler (2011) menyatakan bahwa skema insentif keuangan dapat berfungsi dengan lebih efektif untuk meningkatkan kinerja ketika individu mendapat tugas yang kurang kompleks. Ketika kompleksitas tugas meningkat maka kebutuhan akan pengetahuan dan keterampilan juga meningkat sehingga hal tersebut dapat menyebabkan individu menjadi kurang peka terhadap kinerja yang perlu untuk dicapai. Oktavia dkk. (2014) juga menyatakan bahwa kinerja individu yang menerima insentif keuangan dengan skema piece-rate cenderung lebih tinggi daripada kinerja individu yang menerima insentif keuangan dengan skema flat-rate baik dalam pengerjaan tugas dengan kompleksitas yang rendah. Oleh sebab itu maka dikembangkan hipotesis berikut:

$\mathbf{H}_{3}$ : Dalam kondisi tugas dengan tingkat kompleksitas rendah, individu yang diberikan skema insentif berbasis piece-rate akan memiliki kinerja yang lebih tinggi dibanding individu yang diberi skema insentif berbasis flat-rate.

Model penelitian mencakup ketiga hipotesis dalam penelitian ini dirangkum dalam Gambar 1 berikut:

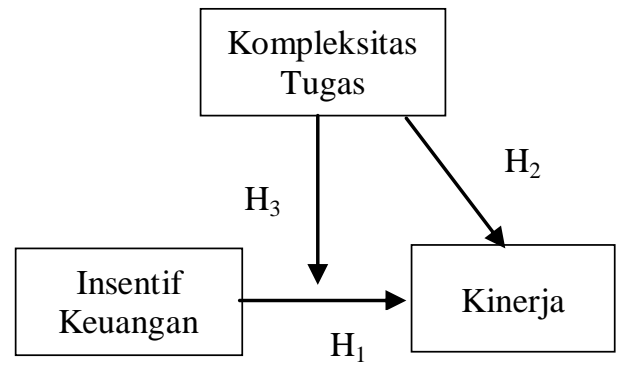

\section{Gambar 1 Model Penelitian}

\section{Metode Penelitian}

\section{Desain Penelitian}

Penelitian ini menggunakan metode eksperimen $2 \times 2$ between-subject untuk mengumpulkan data. Dalam hal ini setiap partisipan yang terlibat dalam studi ini akan mendapatkan perlakuan (treatment) yang berbeda, tergantung pada kondisi dimana partisipan tersebut dialokasikan. Adapun alokasi partisipan ke dalam kelompok sel eksperimen dilakukan secara acak (random) guna menjaga validitas internal. Terdapat dua variabel independen yang akan dioperasionalisasikan dalam studi ini, yakni insentif keuangan (piece-rate dan fixedrate) serta kompleksitas tugas (tinggi dan rendah). Adapun variabel dependen dalam penelitian ini adalah kinerja individu yang diukur berdasarkan jumlah soal tugas eksperimen yang dapat dijawab dengan benar. Desain eksperimen ditampilkan sebagai berikut:

\section{Tabel 1}

\section{Desain Eksperimen 2x2 Between-Subject}

\begin{tabular}{|l|l|}
\hline Sel 1 (Kode A): & Sel 2 (Kode B): \\
$\begin{array}{l}\text { Insentif } \text { flat-rate } \\
\text { Kompleksitas } \\
\text { tugas rendah }\end{array}$ & $\begin{array}{l}\text { Insentif } \text { flat-rate } \\
\text { Kompleksitas } \\
\text { tugas tinggi }\end{array}$ \\
\hline $\begin{array}{l}\text { Sel 3 (Kode C): } \\
\begin{array}{l}\text { Insentif piece-rate } \\
\text { Kompleksitas } \\
\text { tugas rendah }\end{array}\end{array}$ & $\begin{array}{l}\text { Sel 4 (Kode D): } \\
\text { Insentif piece-rate } \\
\text { Kompleksitas } \\
\text { tugas tinggi }\end{array}$ \\
\hline
\end{tabular}

Sumber Tabel: Data olahan

Partisipan yang dialokasikan dalam Sel 1 akan memperoleh insentif keuangan dengan skema flat-rate serta diberikan tugas dengan tingkat kompleksitas rendah. Adapun partisipan yang dialokasikan dalam Sel 2 akan mendapat insentif keuangan dengan skema flat-rate serta tugas dengan tingkat kompleksitas tinggi. Partisipan yang dialokasikan dalam Sel 3 akan memperoleh insentif keuangan dengan skema piece-rate serta diberikan tugas dengan tingkat kompleksitas rendah. Selanjutnya, 
partisipan yang dialokasikan dalam Sel 4 akan memperoleh insentif keuangan dengan skema piece-rate serta diberikan tugas dengan tingkat kompleksitas tinggi.

\section{Partisipan Eksperimen}

Partisipan dalam penelitian ini terdiri dari para mahasiswa jurusan strata 1 (S1) akuntansi pada salah satu universitas swasta di Surabaya, Indonesia. Kriteria partisipan adalah sebagai berikut: (a) Mahasiswa aktif jurusan S1 akuntansi, dan (b) Minimal duduk di tahun kedua (semester III) dari perkuliahan. Penggunaan mahasiswa sebagai partisipan dalam studi ini dilakukan karena tugas yang diberikan dalam studi ini; yaitu decoding-task yang diadaptasi dari Chow (1983); adalah tugas yang relatif mudah untuk dipahami oleh mahasiswa, tidak memerlukan kemampuan atau keahlian khusus dalam pengerjaannya, serta telah berulang-kali diaplikasikan dalam studi eksperimen lainnya yang sejenis (Bonner dkk., 2000; Oktavia dkk., 2014).

\section{Tugas Eksperimen}

Tugas yang digunakan dalam eksperimen ini adalah jenis tugas decoding yang diadaptasi dari studi Chow (1983), dimana partisipan yang mengerjakan tugas ini akan diminta untuk mengkonversikan simbol yang disediakan menjadi rangkaian huruf atau angka tertentu, sesuai dengan kondisi sel mereka. Setiap sel eksperimen terdiri dari 1 ronde utama dengan alokasi waktu selama 3 menit dan jumlah soal sebanyak 22 nomor. Sebelum partisipan masuk ke ronde utama, akan diberikan sesi latihan selama 1 menit dengan 2 nomor soal untuk dapat dikerjakan, serta 2 pertanyaan cek manipulasi yang bertujuan untuk menguji pemahaman partisipan terhadap soal yang diberikan serta mengkonfirmasi tingkat kompleksitas tugas sesuai kondisi sel partisipan.

\section{Pengukuran Variabel}

Variabel independen pertama dalam penelitian ini adalah insentif keuangan yang dibedakan menjadi dua jenis yaitu piecerate dan fixed-rate. Pada skema piece rate, partisipan akan diberikan insentif sejumlah Rp 500,- untuk setiap nomor soal yang berhasil dijawab dengan benar, sedangkan pada skema flat-rate, partisipan akan diberikan insentif bersifat tetap sejumlah Rp 3.000,- untuk partisipasi mereka dalam eksperimen ini, terlepas dari jumlah soal yang berhasil dijawab dengan benar.

Variabel independen kedua dalam penelitian ini adalah kompleksitas tugas yang dibedakan menjadi dua kategori yaitu tinggi dan rendah. Pada kondisi kompleksitas tugas tinggi, partisipan akan diberikan variasi tugas decoding dengan tingkat kompleksitas yang tinggi (terdiri dari 3 komponen yaitu simbol, angka dan huruf) dimana mereka akan diminta untuk mengkonversi simbol yang disediakan menjadi 2 output, yaitu rangkaian angka dan huruf, sedangkan dalam kondisi kompleksitas tugas rendah, partisipan akan diberi variasi tugas dengan tingkat kompleksitas yang lebih rendah (hanya terdiri dari 2 komponen yaitu simbol dan huruf) dimana mereka diminta untuk mengkonversi simbol yang ada menjadi rangkaian huruf.

Variabel dependen dalam penelitian ini adalah kinerja individu yang diukur melalui jumlah tugas decoding yang berhasil dijawab dengan benar oleh setiap partisipan, dimana semakin banyak soal yang dijawab dengan benar mengindikasikan semakin tingginya kinerja dari partisipan tersebut. Terdapat total 22 nomor soal yang dapat dikerjakan oleh partisipan selama 3 menit.

\section{Prosedur Eksperimen}

Berikut adalah prosedur dari eksperimen yang dilakukan:

a. Peneliti mengkondisikan keadaan partisipan di dalam ruang kelas. Setelah partisipan telah berada dalam kondisi 
yang diharapkan, peneliti akan memperkenalkan diri menjelaskan tujuan eksperimen.

b. Partisipan akan dibagikan skenario eksperimen yang telah diberi kode oleh peneliti (A, B, C, D). Pemberian skenario dilakukan secara acak untuk tujuan randomisasi.

c. Setelah partisipan menerima skenario, peneliti akan memberikan instruksi pengerjaan eksperimen terkait apa saja yang perlu dikerjakan dan diperhatikan oleh partisipan.

d. Sebelum memasuki pengerjaan latihan soal eksperimen, partisipan diminta untuk mengisi data demografis berupa jenis kelamin, angkatan perkuliahan, usia, serta indeks prestasi kumulatif.

e. Partisipan masuk ke tahap pengerjaan latihan soal tugas eksperimen. Pada tahap ini partisipan diminta untuk mencoba mengerjakan latihan soal sebanyak 2 nomor selama 1 menit, serta menjawab 2 pertanyaan cek manipulasi yang bertujuan untuk menguji pemahaman partisipan terhadap soal yang diberikan serta mengkonfirmasi tingkat kompleksitas tugas sesuai kondisi sel partisipan.

f. Setelah pengerjaan latihan soal, partisipan diberikan kesempatan untuk bertanya kepada peneliti terkait soal yang dikerjakan. Apabila seluruh pertanyaan partisipan telah terjawab, maka ronde utama pengerjaan soal pun dimulai.

g. Pada ronde utama eksperimen, partisipan akan diberi lembaran berisi 22 nomor soal untuk dapat dikerjakan dalam waktu 3 menit.

h. Setelah waktu 3 menit tersebut habis, partisipan diminta mengumpulkan lembaran soal eksperimen kepada peneliti, dan sesi eksperimen pun selesai. Partisipan diperbolehkan untuk meninggalkan ruang kelas.

i. Peneliti akan memeriksa jawaban dari setiap partisipan dan mengalokasikan insentif kepada setiap partisipan.
Insentif diberikan dalam jangka waktu 1 minggu setelah eksperimen dilakukan.

\section{Hasil Penelitian dan Pembahasan}

\section{Pengecekan Manipulasi}

Sebelum masuk ke tahap utama, setiap partisipan diberikan latihan soal serta 2 pertanyaan cek manipulasi untuk menguji pemahaman mereka tentang tugas dan kondisi yang diberikan. Berikut ini contoh pertanyaan cek manipulasi yang diberikan:

\begin{tabular}{|c|c|}
\hline \multirow{2}{*}{$\begin{array}{c}\text { Apakah anda memahami } \\
\text { pekeriaan yang akan anda } \\
\text { lakukan? }\end{array}$} & YA \\
\hline & TIDAK \\
\hline \multirow{2}{*}{$\begin{array}{l}\text { Menurut anda, apakah } \\
\text { pekeriaan anda termasuk } \\
\text { pekerjaan yang mudah? }\end{array}$} & YA \\
\hline & TIDAK \\
\hline
\end{tabular}

\section{Gambar 2}

Pertanyaan Cek Manipulasi

Untuk dapat dikategorikan lolos cek manipulasi, partisipan perlu untuk melakukan ketiga hal berikut: (a) Menjawab dengan benar 2 soal latihan yang diberikan, (b) Menjawab "Ya" untuk pertanyaan "Apakah anda memahami pekerjaan yang akan anda lakukan?" serta (c) Menjawab "Ya" atau "Tidak" terhadap pertanyaan "Menurut anda, apakah pekerjaan anda termasuk pekerjaan yang mudah?" tergantung dari tingkat kompleksitas tugas dimana partisipan tersebut dialokasikan. Apabila partisipan dialokasikan pada kondisi kompleksitas tugas rendah, maka ekspektasi jawaban partisipan terhadap pertanyaan tersebut adalah "Ya", dan sebaliknya, ekspektasi jawaban partisipan adalah "Tidak" apabila partisipan tersebut dialokasikan pada kondisi dengan kompleksitas tugas yang tinggi.

Pada tahap awal, terdapat 126 partisipan yang mengikuti eksperimen. Dari jumlah tersebut diketahui terdapat 27 partisipan yang tidak lolos cek manipulasi, sehingga menghasilkan total 99 orang 
partisipan yang dapat digunakan untuk masuk ke tahap analisis data. Adapun distibusi dari 99 orang partisipan tersebut kedalam 4 sel eksperimen dalam penelitian ini adalah sebagai berikut: Sel A (insentif flat-rate, kompleksitas tugas rendah) terdiri dari 28 partisipan, Sel B (insentif flat-rate, kompleksitas tugas tinggi) berjumlah 25 partisipan, Sel C (insentif piece-rate, kompleksitas tugas rendah) terdiri atas 23 partisipan, dan Sel D (insentif piece-rate, kompleksitas tugas tinggi) berjumlah 23 partisipan.

\section{Pengujian Randomisasi}

Tabel 2 menampilkan profil partisipan secara demografis berdasarkan jenis kelamin, usia dan indeks prestasi kumulatif. Sebelum dilakukan pengujian hipotesis, terlebih dahulu akan dilakukan pengujian atas randomisasi untuk mengetahui kemungkinan pengaruh dari faktor-faktor demografis tersebut terhadap kinerja partisipan. Tabel 3 menampilkan hasil uji One-Way Anova untuk melihat efek randomisasi. Dalam hal ini, ketiga faktor demografis tersebut (jenis kelamin, usia dan indeks prestasi) memiliki nilai signifikansi $>0.05$ yang berarti bahwa kinerja partisipan dalam eksperimen ini tidak dipengaruhi oleh jenis kelamin, usia serta indeks prestasi mereka. Oleh sebab itu dapat disimpulkan bahwa randomisasi telah berhasil dilakukan karena kinerja partisipan tidak dipengaruhi oleh faktor demografis yang berada di luar kontrol peneliti.
Tabel 2

Profil Partisipan

\begin{tabular}{|ccc|}
\hline Keterangan & Total & Persentase \\
\hline Jenis Kelamin & & \\
Pria & 19 & $19.2 \%$ \\
Wanita & 80 & $80.8 \%$ \\
Usia & & \\
18 & 5 & $5 \%$ \\
19 & 27 & $27.3 \%$ \\
20 & 47 & $47.5 \%$ \\
21 & 15 & $15.2 \%$ \\
22 & 3 & $3 \%$ \\
$>22$ & 2 & $2 \%$ \\
Indeks Prestasi & & \\
$<3.00$ & 26 & $26.3 \%$ \\
$3.00-3.25$ & 23 & $23.2 \%$ \\
$3.26-3.50$ & 21 & $21.2 \%$ \\
$>3.50$ & 29 & $29.3 \%$ \\
\hline
\end{tabular}

Sumber Tabel: Data olahan

Tabel 3

\section{Hasil Pengujian One-Way ANOVA}

\begin{tabular}{|lcc|}
\hline Keterangan & F & Sig. \\
\hline Jenis Kelamin & 0.631 & 0.429 \\
Usia & 1.482 & 0.202 \\
Indeks Prestasi & 1.868 & 0.140 \\
\hline
\end{tabular}

Sumber Tabel: Data olahan

\section{Pengujian Hipotesis}

\section{a. Hipotesis 1}

Hipotesis 1 memperkirakan bahwa partisipan yang diberikan insentif keuangan berskema piece-rate akan mempunyai kinerja yang lebih tinggi dibanding individu yang diberikan insentif keuangan dengan skema flat-rate. Hasil pengujian Hipotesis 1 ditampilkan di Tabel 4. 


\section{Tabel 4}

\section{Hasil Pengujian Hipotesis 1}

\begin{tabular}{|l|c|c|c|}
\hline \multicolumn{1}{|c|}{$\begin{array}{c}\text { Skema } \\
\text { Insentif }\end{array}$} & $\begin{array}{c}\text { Mean } \\
(\mathrm{SD})\end{array}$ & $\mathrm{t}$ & Sig \\
\cline { 1 - 2 } $\begin{array}{l}\text { Flat-rate } \\
(n=53)\end{array}$ & $\begin{array}{c}11.60 \\
(5.03)\end{array}$ & \multirow{2}{*}{0.186} & \multirow{2}{*}{0.853} \\
\cline { 1 - 2 } $\begin{array}{l}\text { Piece-rate } \\
(n=46)\end{array}$ & $\begin{array}{c}11.41 \\
(5.14)\end{array}$ & & \\
\hline \multicolumn{2}{|l|}{ Selisih mean: 0.21} \\
\hline \multicolumn{2}{|l|}{ Variabel dependen: Kinerja } \\
\hline
\end{tabular}

Sumber Tabel: Data olahan

Berdasarkan Tabel 4, diketahui bahwa ratarata kinerja partisipan dengan skema insentif flat-rate adalah sebesar 11.60 (5.03) sedangkan rata-rata kinerja partisipan dengan skema insentif piece-rate adalah senilai 11.41 (5.14). Perbedaan kinerja antara dua kategori tersebut adalah senilai 0.21 dengan nilai t yaitu 0.186 dan tingkat signifikansi 0.853 . Hasil ini tidak mendukung prediksi hipotesis 1 , dimana hasil pengujian menyatakan bahwa tidak terdapat perbedaan secara signifikan dalam hal kinerja individu berdasarkan pada skema insentif (piece-rate dan flat-rate) yang diberikan.

Ada beberapa faktor yang perlu diperhatikan oleh perusahaan dalam mendesain skema insentif yang dapat diaplikasikan secara di dalam perusahaan. Faktor-faktor tersebut antara lain: jenis pekerjaan, karakteristik dan kemampuan karyawan serta jumlah sumber daya yang dimiliki oleh perusahaan sendiri (Fehrenbacher, Kaplan dan Pedell, 2017). Lebih lanjut terkait hal ini, Grabner (2014) mengemukakan bahwa skema insentif berbasis kinerja (performance-based incentive) tidak selalu merupakan bentuk skema insentif yang paling sesuai untuk diterapkan di dalam perusahaan, terutama dalam organisasi yang dinamis serta mengedepankan unsur kreatifitas dalam menghasilkan output. Sebab karakteristik obyektif yang melekat pada skema insentif berbasis kinerja akan sulit untuk dapat membawa hasil yang efektif apabila tidak didukung oleh unsur subyektifitas dalam penilaian kinerja (subjective performance evaluation). Oleh sebab itu, dapat dikatakan bahwa skema insentif berbasis piece-rate; yang menggunakan kinerja yang dihasilkan sebagai dasar pengalokasian insentif; tidak selalu efektif untuk dapat diaplikasikan didalam organisasi.

\section{b. Hipotesis 2}

Hipotesis 2 memprediksi bahwa partisipan yang diberikan tugas dengan tingkat kompleksitas yang rendah akan memiliki kinerja yang lebih tinggi dibanding partisipan yang diberi tugas dengan tingkat kompleksitas tinggi. Tabel 5 menampilkan hasil independent sample t-test untuk menguji hipotesis 2 dalam penelitian ini.

\section{Tabel 5}

\section{Hasil Pengujian Hipotesis 2}

\begin{tabular}{|l|c|c|c|}
\hline $\begin{array}{c}\text { Komplek- } \\
\text { sitas Tugas }\end{array}$ & $\begin{array}{c}\text { Mean } \\
(\mathrm{SD})\end{array}$ & $\mathrm{t}$ & Sig \\
\hline Rendah & $\begin{array}{c}15.13 \\
(3.96)\end{array}$ & \multirow{2}{*}{10.993} & $<0.01$ \\
$(n=51)$ & $\begin{array}{c}7.66 \\
(2.70)\end{array}$ & & \\
\hline $\begin{array}{l}\text { Tinggi } \\
(n=48)\end{array}$ & & \\
\hline \multicolumn{2}{|l|}{ Selisih mean: 7.47} \\
\hline \multicolumn{2}{|l|}{ Variabel dependen: Kinerja } \\
\hline
\end{tabular}

Sumber Tabel: Data olahan

Berdasarkan tabel diatas, rata-rata kinerja partisipan dalam kondisi kompleksitas tugas rendah adalah sebesar 15.13 (3.96) yang lebih tinggi dibanding partisipan dalam kondisi kompleksitas tugas yang tinggi, yaitu 7.66 (2.70). Adapun selisih kinerja antara partisipan dalam kedua kategori tersebut adalah 7.47 dengan nilai t sebesar 10.993 dan tingkat signifikansi $<0.01$. Hasil ini mendukung hipotesis 2 , dimana rata-rata kinerja partisipan dalam kondisi kompleksitas tugas rendah memiliki perbedaan secara signifikan dengan partisipan dalam kondisi kompleksitas tugas tinggi. 
Hasil ini sejalan dengan temuan-temuan dari penelitian Oktavia dkk. (2014) serta Bailey dan Fessler (2011) yang menyatakan bahwa tingkat kompleksitas tugas yang rendah akan mampu memfasilitasi kinerja individu ke arah yang lebih tinggi. Tugas dengan tingkat kompleksitas ynag tinggi memerlukan intensitas, koordinasi, pemahaman dan strategi yang secara proporsional lebih tinggi dibanding tugas dengan tingkat kompleksitas yang rendah, dimana hal-hal tersebut cenderung sulit untuk dapat dipenuhi oleh individu dalam beberapa kondisi tertentu, seperti adanya keterbatasan waktu dan sumber daya (Haerem dkk., 2015).

\section{c. Hipotesis 3}

Hipotesis 3 dalam penelitian ini memperkirakan bahwa dalam kondisi dimana tingkat kompleksitas tugas rendah, individu yang diberikan skema insentif piece-rate akan menghasilkan kinerja yang lebih tinggi dibanding individu yang diberikan skema insentif flat-rate. Tabel 6 menampilkan hasil pengujian pengaruh interaksi antara insentif keuangan dan kompleksitas tugas terhadap kinerja.

\section{Tabel 6}

\section{Hasil Pengujian Hipotesis 3}

\begin{tabular}{|c|c|c|c|}
\hline Keterangan & $\begin{array}{l}\text { Mean } \\
\text { Square }\end{array}$ & $\mathrm{F}$ & Sig. \\
\hline $\begin{array}{l}\text { Skema } \\
\text { Insentif }\end{array}$ & 0.022 & 0.002 & 0.965 \\
\hline $\begin{array}{l}\text { Komplek- } \\
\text { sitas } \\
\text { Tugas }\end{array}$ & $\begin{array}{l}1363 . \\
439\end{array}$ & $\begin{array}{l}114 . \\
674\end{array}$ & $<0.01$ \\
\hline $\begin{array}{l}\text { Skema } \\
\text { Insentif* } \\
\text { Komplek- } \\
\text { sitas tugas }\end{array}$ & 3.176 & 0.267 & 0.606 \\
\hline \multicolumn{4}{|c|}{ Variabel dependen: Kinerja } \\
\hline
\end{tabular}

Sejalan dengan hasil pengujian dua hipotesis sebelumnya $(\mathrm{H} 1$ dan $\mathrm{H} 2)$, dapat dilihat bahwa insentif keuangan tidak berpengaruh terhadap kinerja, dan sebaliknya kompleksitas tugas berpengaruh secara signifikan terhada kinerja. Adapun hasil interaksi antara insentif keuangan dan kompleksitas tugas (H3) menunjukkan hasil yang tidak signifikan yaitu 0.606, yang berarti bahwa tidak ada pengaruh interaksi antara insentif keuangan dan kompleksitas tugas terhadap kinerja individu. Dengan demikian maka hipotesis 3 dalam penelitian ini tidak terdukung.

Dalam penelitian ini dapat dilihat bahwa individu yang diberikan tugas dengan tingkat kompleksitas yang rendah apabila dikaitkan dengan skema insentif, baik flat-rate maupun piece-rate tidak memiliki perbedaan yang signifikan. Hal tersebut diakibatkan individu tersebut dimungkinkan memiliki tujuan untuk menyelesaikan semua tugas yang diberikan dengan optimal tanpa memperhatikan insentif yang diberikan. Kondisi ini dapat terjadi dikarenakan, pada kondisi lingkungan kerja tertentu, faktor insentif yang diberikan oleh organisasi kepada para karyawannya dianggap bukan merupakan faktor terpenting yang mempengaruhi kinerja karyawan tersebut (Oktavia dkk., 2014). Dalam hal ini, Grabner (2014) berpendapat bahwa kondisi yang umumnya terjadi didalam praktik perusahaan secara garis besar adalah bahwa jenis insentif yang diberikan kepada karyawan ditetapkan secara top-down oleh manajemen perusahaan tanpa mempertimbangkan karakteristik karyawan serta jenis pekerjaan mereka. Akibatnya adalah, kinerja dari karyawan menjadi kurang optimal, dimana hal tersebut dapat berdampak pula pada kinerja organisasi secara jangka panjang (Grabner, 2014).

Lebih lanjut, Fehrenbacher dkk., (2017) mengemukakan bahwa efektifitas dari skema insentif yang diberikan oleh organisasi dipengaruhi oleh karakteristik karyawan yang terbagi dalam tiga kategori, yakni kemampuan karyawan dalam melakukan tugasnya, preferensi risiko tiaptiap karyawan serta aspek psikologis dari 
karyawan tersebut. Oleh sebab itu, perusahaan disarankan untuk dapat mempertimbangkan hal-hal tersebut dalam menyusun skema insentif keuangan yang akan diaplikasikan, sehingga dapat mendatangkan hasil sesuai dengan yang diharapkan (Fehrenbacher, dkk., 2017).

\section{Simpulan dan Saran}

\section{Simpulan}

Penelitian ini menggunakan metode eksperimen untuk mengamati hubungan antara insentif keuangan, kompleksitas tugas dan kinerja. Berdasarkan hasil pengujian terhadap hipotesis, dapat disimpulkan ketiga hal berikut. Pertama, diketahui bahwa skema insentif tidak berpengaruh terhadap kinerja individu. Dalam hal ini penerapan insentif keuangan berbasis flat-rate dan piece-rate tidak mempengaruhi kinerja yang dihasilkan. Hal ini menunjukkan bahwa individu menganggap penyelesaian tugas yang dipercayakan kepada mereka adalah hal yang lebih penting dibanding jenis insentif yang akan diterima. Hal ini sejalan dengan penelitian dari Fehrenbacher dkk., (2017) yang menyatakan bahwa karakteristik seseorang dapat mempengaruhi tingkat efektifitas dari jenis insentif yang diberikan oleh organisasi kepadanya.

Kedua, kompleksitas tugas diketahui memiliki pengaruh yang signifikan terhadap kinerja individu. Kesimpulan ini menunjukkan bahwa individu yang memperoleh tugas dengan tingkat kompleksitas rendah dapat menghasilkan kinerja yang lebih tinggi dibandingan individu yang memperoleh tugas dengan kompleksitas tinggi. Hal ini sesuai dengan penelitian dari Bailey dan Fessler (2011) yang menyimpulkan bahwa efektifitas kinerja dapat bergantung pada tingkat kerumitan dari tugas yang dikerjakan.

Ketiga, penelitian ini juga menemukan bahwa tidak terdapat interaksi antara insentif keuangan dan tingkat kompleksitas tugas terhadap kinerja. Kesimpulan ini menunjukkan bahwa faktor insentif keuangan dan tingkat kompleksitas tugas adalah dua hal yang berbeda dan tidak saling berhubungan dalam kaitannya dengan kinerja seseorang di dalam organisasi, selain itu hal ini juga membuktikan bahwa terdapat beberapa faktor yang mempengaruhi bagaimana personil didalam perusahaan dapat bekerja dengan optimal, dan menjadi tugas dari perusahaan untuk dapat menginvestigasi hal tersebut sehingga dapat membawa perusahaan kepada tingkat kinerja yang lebih optimal (Grabner, 2014).

Berdasarkan ketiga temuan tersebut, dapat disimpulkan dari penelitian ini bahwa insentif keuangan bukanlah merupakan faktor utama yang mempengaruhi kinerja karyawan di dalam perusahaan. Selain itu faktor tingkat kompleksitas dari tugas yang diberikan oleh perusahaan kepada karyawannya adalah hal yang penting untuk diperhatikan, sebab kinerja karyawan dapat dipengaruhi oleh hal tersebut.

\section{Saran}

Terdapat beberapa hal yang menjadi keterbatasan dan saran terkait dengan penelitian ini. Pertama, penggunaan mahasiswa S1 akuntansi sebagai partisipan yang mengasumsikan peran sebagai karyawan perusahaan dapat mempengaruhi tingkat generalisasi dari hasil penelitian ini. Penelitian selanjutnya dapat mempertimbangkan penggunaan mahasiswa pascasarjana (S2) sebagai partisipan dengan mempertimbangkan tingkat pengalaman kerja serta pengetahuan yang dimiliki mahasiswa pascasarjana akan dapat berkontribusi terhadap tingkat generalisasi dari hasil penelitian.

Kedua, penggunaan tugas dan tahapan eksperimen yang merupakan gambaran sederhana dari kondisi yang dialami oleh karyawan pada dunia kerja dapat mempengaruhi aspek validitas eksternal dari penelitian ini. Dalam hal ini, penelitian selanjutnya dapat mempertimbangkan penggunaan tugas dan tahapan yang lebih 
disesuaikan dengan kondisi nyata di dunia kerja. Ketiga, penelitian ini hanya mempertimbangkan dua faktor yang diteliti hubungannya terhadap kinerja individu, yakni skema insentif keuangan dan tingkat kompleksitas tugas, dimana terdapat pula faktor-faktor lain yang sekiranya dapat diteliti oleh studi-studi berikutnya terkait dengan hubungannya terhadap kinerja, seperti persepsi mengenai prosedur perusahaan dari sudut pandang karyawan (Yusnaini, 2010), serta penggunaan umpan balik dan informasi relatif terkait kinerja personil didalam organisasi (Ludji, 2018).

\section{Daftar Pustaka}

Bailey, C.D., \& Fessler, N.J. (2011). The moderating effects of task complexity and task attractiveness on the impact of monetary incentives in repeated tasks. Journal of Management Accounting Research, 23, 189-210.

Bonner, S.E., Hastie, R., Sprinkle, G.B., \& Young, S.M. (2000). A review of the effects of financial incentives on performance in laboratory tasks: Implications for management accounting. Journal of Management Accounting Research, 12(1), 19-64.

Bonner, S.E., \& Sprinkle, G.B. (2002). The effects of monetary incentives on effort and task performance: Theories, evidence, and a framework for research. Accounting, Organizations and Society, 27(4-5), 303-345.

Chow, C.W. (1983). The effects of job standard tightness and compensation scheme on performance: an exploration of linkages. The Accounting Review, 58, 667-685.

Fehrenbacher, D.D., Kaplan, S.E. \& Pedell, B. (2017). The relation between individual characteristics and compensation contract selection.
Management Accounting Research, 34, 1-18.

Gong, Z. \& Ferreira, A. (2014). Does consistency in management control systems design choices influence firm performance? An empirical analysis. Accounting and Business Research, 44(5), 497-522.

Grabner, I. (2014). Incentive system design in creativity-dependent firms. The Accounting Review, 89(5), 1729-1750.

Haerem, T., Pentland, B.T., \& Miller, K.D. (2015). Task complexity: Extending a core concept. Academy of Management Review, 40(3), 446460.

Hall, M. (2011). Do comprehensive performance measurement systems help or hinder managers' mental model development. Management Accounting Research, 22(2), 68-83.

Hilton, R.W., \& Platt, D.E. (2011). Managerial accounting: Creating value in a global business environment (9th edition). New York, NY: McGraw-Hill/Irwin.

Iskandar, T.M. \& Sanusi, Z.M. (2011). Assessing the effects of self-efficacy and task complexity on internal control audit judgment. Asian Academy of Management Journal of Accounting and Finance, 7(1), 2952.

Liu, P., \& Li, Z. (2012). Task complexity: A review and conceptualization framework. International Journal of Industrial Ergonomics, 42, 553-568.

Ludji, T.R. (2018). Experimental examination of the relationship between relative performance information, goal setting and performance. Asian Journal of Business and Accounting, 11(2), 215-247.

Moeheriono. (2012). Pengukuran Kinerja Berbasis Kompetensi (edisi revisi). Jakarta: Raja Grafindo Persada. 
Oktavia, Rossieta, H. \& Gani, L. (2014). Dampak insentif moneter terhadap kinerja individu: Peran dari kompleksitas tugas dan target kinerja. Jurnal Akuntansi, 14(1), 2544.

Sudarma, K. (2012). Mencapai sumber daya manusia unggul (Analisis kinerja dan kualitas pelayanan). Jurnal Dinamika Manajemen, 3(1), 76-83.

Yusnaini (2010). Analisis fairness dan incentive contracting pada kinerja berbasis anggaran: Pengujian eksperimen atas referent cognition theory. Jurnal Akuntansi dan Keuangan, 12(1), 9-16. 